\title{
Original
}

\section{The Effects of Different Black Mediators on the Shear Strength of Orthodontic Bracket to the Enamel Treated with Nd-YAG Laser}

\author{
Shun-Te Huang, I-Shueng Lin and Chia-Ling Tsai \\ Department of Pediatric Dentistry, School of Dentistry, \\ Kaohsiung Medical College
}

(Accepted for Publication: January 30, 1995)
$\mathrm{Nd}$ ：YAG レーザー照射時の各種黒色塗布材による 牛のエナメル質表面の形態変化について 黄純 徳林易萱蔡佳 玲 高雄医学院牙医系
(受理 : 平成 7 年 1 月 31 日)

\begin{abstract}
要旨: 本研究は, 各種黑色塗布材を併用して Nd-YAG レーザーによるエナメル質表層脱灰後の歯列矯正 用ブラケットの接着性を検討することを目的に行われた。被験歯として72本の牛の歯が使用された。実験群 としては, 対照群, 酸処理群, レーザー処理群の三つの群に分類した。レーザー装置として, ADL の300dl を用い，20pps， 87．5 mJ の照射条件でレーザーエッチングを行った。接着力（shear strength）は Instion を使用して測定した。その結果, レーザー処理群よりも酸処理群の方が shear strength は強かっ た。なお, 酸処理群中では, phosphoric acidの方が maleic acidを用いた場合よりも強かった。黒色 塗布材併合のレーザー処理群の中では, 黒と oil ink 併用群が最も shear strength が強く, ball pen と water ink の群は次に強い值を示した。transfer paper を用いた場合が最も弱い值を示した。
\end{abstract}

(J. Jpn. Soc Laser Dent. 6:46 50, 1995 Reprints request to Dr. Huang)

Key words=Nd : YAG Laser : Black mediators : Shear strength : Bovine enamel : Acid etching

キーワード=Nd：YAG レーザー：黒色塗布材：引つ張り強さ：牛の歯エナメル質：酸エッチング

\section{Introduction}

The acid etching method can dissolve some part of enamel surface to produce the effect of enamel tags ${ }^{1)}$. In orthodontics, these enamel tags will provide a very strong anchorage effect to hold the orthodontic brackets by bonding materials such as composite resins ${ }^{2}$.

The laser can make a rough enamel surface, and different energies of lasers have different effects on the enamel, such as ablation, crack, and crater ${ }^{3-6)}$. These effects are very similar to the effect of enamel tags produced by the acid etching method ${ }^{5,6}$. So the treatment of enamel surface by the dental laser was developped in orthodontic field recently ${ }^{7-10)}$.

The roughness of enamel surface was depended on the different laser energy levels

*100 Shih-Chuan 1st Rd. Kaohsiung City, Taiwan. R. O.C.

TEL : (07) 3121101 ext. 7004, 2158 FAX : (07) 3210637

* 台湾高雄市十全一路100号 電話 07-3121101 内線 7004，2158 FAX 07-3210637 
which may be modified by the different black mediators $^{11)}$. This study was designed to understand the shear strengths of orthodontic brackets bonded to the different black mediators prepainted and laser radiated enamel surfaces. The effects of laser etching were compared with the effects of acid etching.

\section{Materials and Methods}

Labial enamels of 72 matured bovine teeth were grounded and polished with sand paper (from 320 \# to $600 \#$ ) until the smooth surfaces appeared. The samples were then cut into a block size of $10 \mathrm{~mm} \times 8 \mathrm{~mm}$, and afterwards embedded and divided into 3 main groups and 8 subgroups :

1) control group

2) acid etching group pretreated with acid solutions :
a) $37 \%$ phosphoric acid subgroup
b) $10 \%$ maleic acid subgroup

3) laser group pretreated with 5 different kinds of black mediators:
a) Chinese ink subgroup
b) black oil ink subgroup
c) black ball pen subgroup
d) black water ink subgroup
e) black transfer paper subgroup

Each subgroup contained 9 specimens.

The size of labial surfaces of bovine enamels for acid etching and black mediators painting was about $3.5 \mathrm{~mm} \times 5.5 \mathrm{~mm}$.

There was no treatment on the labial surfaces of bovine enamel for control group.

The etching time for phosphoric acid and maleic acid was according to the manual of products as 1 minute and 15 seconds respectively. After the etching procedure, the samples were rinsed and dried.

Chinese ink and black oil ink were sticky and waterproof, black ball pen and black water ink were watery in character, and black transfer paper was easier to identify the size. After the above painting procedures, the samples were lased with Nd-YAG laser according to the method of previous study ${ }^{7}$.

The laser machine used was the American
Dental Laser ADL model d Lase 300. Its wave lehgth is $1064 \mathrm{~nm}$, and its pulse width is 150 . The spot size of its focus is 400 micron in diameter, and the fiber size is 320 microns. The distance between object and fiber tip is $0.16 \mathrm{~m}$ $\mathrm{m}$. The power is $20 \mathrm{pps}, 87.5 \mathrm{~mJ}$. The reason why chose these conditions was because in a previous experiment ${ }^{7)}$ we had found such condition the best for laser treatment. Orthodontic brackets were bonded to the prepared tooth samples with composite resin (Ormco Co.) for testing shear strength. The shear strengths of enamel surfaces to the orthodontic brackets were measured by Instron 1125 .

\section{Results}

The results of the shear strength experiments were shown in Table 1.

The control group did not show any significant bonding force between enamel and bracket. Acid etching enamels, either by phosphoric acid or maleic acid, had stronger shear strength than the laser lased enamels significantly. The phosphoric acid subgroup had stronger shear strength than the maleic aicd subgroup. In the laser group, Chinese ink subgroup and oil ink subgroup had stronger shear strength than black ball pen subgroup and water ink subgroup significantly. The black transfer paper subgroup had the weakest shear strength in the laser group (Table 2).

There is not statictically significant difference

Table 1 Shear Strength of Orthodontic Brackets to Enamels Treated with Acid Etched or Laser Etched Methods

\begin{tabular}{llll}
\hline Control group & $:$ & 0 & $(\mathrm{~kg})$ \\
\hline Acid etching group : & & \\
Phosphoric acid subgroup & $:$ & $19.97 \pm 2.77$ \\
Maleic acid subgroup & $:$ & $17.14 \pm 4.71$ \\
\hline Laser group & & \\
Chinese ink subgroup & $:$ & $6.35 \pm 2.21$ \\
Black oil ink subgroup & $:$ & $6.33 \pm 1.99$ \\
Black ball pen subgroup & $:$ & $4.41 \pm 1.09$ \\
Black water ink subgroup & $:$ & $5.08 \pm 2.59$ \\
Black transfer paper subgroup & $:$ & $3.34 \pm 3.14$ \\
\hline
\end{tabular}


Table 2 The t-test for the Shear Strength of Orthodontic Brackets to Enamels Treated with Acid Etched or Laser Etched Methods

\begin{tabular}{l|ccccccc}
\hline & $\mathrm{Ph}$ & $\mathrm{Ma}$ & $\mathrm{Ci}$ & $\mathrm{Bo}$ & $\mathrm{Bb}$ & $\mathrm{Bw}$ & $\mathrm{Bt}$ \\
\hline $\mathrm{Ph}$ & - & $\mathrm{np}$ & $*$ & $*$ & $*$ & $*$ & $*$ \\
$\mathrm{Ma}$ & - & - & $*$ & $*$ & $*$ & $*$ & $*$ \\
$\mathrm{Ci}$ & - & - & - & $\mathrm{np}$ & $*$ & $*$ & $*$ \\
$\mathrm{Bo}$ & - & - & - & - & $*$ & $*$ & $*$ \\
$\mathrm{Bb}$ & - & - & - & - & - & $\mathrm{np}$ & $\mathrm{np}$ \\
$\mathrm{Bw}$ & - & - & - & - & - & - & $*$ \\
$\mathrm{Bt}$ & - & - & - & - & - & - & - \\
\hline
\end{tabular}

* : $\mathrm{P}<0.05$

$\mathrm{Ph}$ : Phosphoric acid Ma : Maleic acid

$\mathrm{Ci}$ : Chinese ink Bo: Black oil ink

$\mathrm{Bb}$ : Black ball pen Bw : Black water ink

Bt : Black transfer paper

in shear strengths either between the Chinese ink subgroup and oil ink subgroup or between the black ball pen subgroup and water ink subgroup (Table 2).

\section{Discussion}

$\mathrm{J} \mathrm{ffe}^{12)}$ reported that enamel can be laser-etched to a depth comparable to that achieved with phosphoric acid etching. Myers ${ }^{13,14)}$ found that both the acid and laser energy penetrated the enamel to approximately the same depth from 20-40 microns, and that morphologic changes in enamel were very similar between the two techniques.

Abed $^{15)}$ compared the abhesion power of orthodontic brackets to the $37 \%$ phosphoric acid and the Nd-YAG laser etched tooth enamels and reported that abhesion was greater with acid than with laser etching.

Huang $^{16)}$ found that a although the shear strength of orthodontic brackets to bovine enamel surfaces showed greater in phosphoric acid etched group than in laser etched group, but the strength produced by laser irradiation was still greater than the force needed for the orthodontic tooth body movement.

Hess $^{4)}$ observed the coated enamel surface irradiated with $35 \mathrm{~mJ}$ energy level of $\mathrm{Nd}-\mathrm{YAG}$ laser had melted and reconstructed with numerous small, bubble-like inclusions. The $75 \mathrm{~mJ}$ energy level showed individual impact craters with shallow centers and raised edges containing numerous pores and large bubble-like inclusions ${ }^{4)}$. So Hess ${ }^{4)}$ concluded that many bubblelike inclusions varying in size due to the different energy levels.

Morioka $^{11)}$ had mentioned about the pretreatment of different mediators would cause different levels of laser energy absorption at this surfaces, therefore different effects on the enamel surfaces could be observed.

We chose five different kinds of mediators for this experiment. The results of 5 laser subgroups can be divided into 3 groups. The first group was painted with waterproof and oil-like mediators including Chinese ink, and black oil ink, which are more sticky and have more particles in the suspension. These two subgroup showed the strongest shear strength in the laser group. The second group was consisted of black ball pen subgroup and black water ink subgroup which were characterized with watery content and less particles. They showed moderate shear strength in this experiment. The third group was painted with black transfer paper. Due to its homogenous character and easily to be identified in size, we included transfer paper as one subgroup in our experiment. This subgroup did not show enough shear strength to hold the orthodontic brackets.

The phosphoric acid solution is the most popular and well studied acid etching solution ${ }^{2}$. Enamel surfaces etched with this solution had the strongest shear strength in the whole experiment. Our data was very similar to that of other researches ${ }^{8,15)}$. Another one, maleic acid ${ }^{17)}$, has been used to prepare the hard tissue for bonding since 1987 and was lower consistency than the traditional phosphoric $\operatorname{acid}^{17,18)}$. The maleic acid subgroup did not show similar strong shear strength as phosphoric acid subgroup, but was stronger than that of laser group.

So from the sbove data, although most of studies $^{3-7,9,12-16)}$ agreed that phosphoric acid etching method produce stronger shear strength 
between enamel surface and orthodontic brackets, and more retentive topographic change on the enamel surface than laser etched method, laser etched method still have enough shear strength to hold the brackets for orthodontic movement of teeth, and cause an unevent and complex surface change on the enamel surface. In addition, laser etched method has some benefits such as easily to identify the etching area, less procedures, less discomfortability for the patients, and more resistance to the caries which is always a big problem for young persons who have orthodontic brackets in their mouth $^{15, i \epsilon)}$. We suggest that the etching of Chinese ink prepainted enamel surface lased with Nd-YAG laser at $20 \mathrm{pps}, 87.5 \mathrm{~mJ}$, has its practical benefits over traditional phosphoric acid etched method.

\section{Conclusions}

Seventy-two enamel surfaces of bovine lower anterior incisors were pretreated with phosphoric acid, maleic acid, or prepainted with 5 kinds of black mediators and lased with 20pps, $87.5 \mathrm{~mJ}$ of $\mathrm{Nd}-\mathrm{YAG}$ laser.

The acid etching group, either by phosphoric acid or maleic acid, has stronger shear strength than the laser group. In the laser group, the Chinese ink subgroup had stronger shear strength than other subgroups.

Although the acid etching group had stronger shear strength than the lased group, the $\mathrm{Nd}$ YAG laser technique does have its advantages, such as an easier identification of the pretreated areas, shorter pretreatment duration, and less patient discomfort. The enamel surfaces painted with Chinese ink and lased by the Nd-YAG laser under the condition of $20 \mathrm{pps}, 87.5 \mathrm{~mJ}$ may be suitable for bonding orthodontic brackets in human orthodontic treatment.

\section{Acknowledgement}

This research was supported by National Scientific Council (NSC 83-0412-B037-035).

\section{References}

1) Buonocore, M. G. : A simple method of increasing the abhesion of acrylic filling materials to enamel surfaces. J. Dent. Res., 34(6) : 849-953, 1955.

2) Graber, T. M., Swain, B. F. : Orthodontics, -current principles and Techniques. The C. V. Mosby Company St. Louis 485-505, 1985.

3) Stern, R. H., Sognnaes, R. F. : Laser beam effect on dental hard tissue. J. Dent. Res., 43:873-876, 1964.

4) Hess, J. A. : Scanning electron microscopic study of laser-induced morphologic changes of a coated enamel surface. Lasers Surg. Med. 10 : 458-462, 1990.

5) Goodman, B. D., Gwinnett, A. J. : A comparison of laser-and acid-etched human enamel using scanning electron microscopy. Archs, Oral. Biol., 22 : 215-220, 1977.

6) Liberman, R., Segal, T. H., Nordenberg, D., Serebro, L. I. : Abhesion of composite materials to enamel : comparison between the use of acid and lasing as pretreatment. Lasers Surg. Med., 4:323-327, 1984.

7) Lin, I. S. and Huang, S. T. : The comparison of shear bond strength of orthodontic brackets to bovine enamel pretreated by different conditions of $\mathrm{Nd}-\mathrm{YAG}$ laser. Kaohsiung J. Med. Sci., 10 : 100-105, 1994.

8) Hess, J., Sbed, S. and Shivapuja, P. K. : Bond strength of orthodontic brackets to acid-etched and laser-etched enamel. abstract, Intern. academy of laser dent, Bos-ton, Massachusetts, Oct. 13, 1990.

9) Roberts-Harry, D. P. : Laser etching of teeth for orthodontic brackets placement; a preliminary clinical study. Laser Surg. Med., $12:$ 467-470, 1992.

10) Choe, D. P., Kipnis, V., Singer J. and Voss, R. : The effectiveness of the $308 \mathrm{~nm}$ excimer laser for pretreatment of enamel surface : a comparative study of shear bond strength between laser irradiation and acid etching. Am J Orthod Dentofac Orthop. 488, 1992.

11) Morioka, T., Suzuki, K. and Tagomori, S. : Effect of beam absorptive mediators on an acid-resistance of surface enamel by $\mathrm{Nd}-\mathrm{YAG}$ laser irradiation. J. Dent. Health., 34:40-44, 1984

12) Joffe, S. N., Atsumi, K., and Myers, T. D. : Effects of pulsed Nd-YAG laser on enamel and dentin. Proc. SPIE, 1200, 425-436, 1990.

13) Myers, T. D., Riddle, J. M. : Comparative morphological effects of enamel etching with phosphoric acid and a pulsed Nd-YAG laser. Second international society of laser dentistry. world congress, Paris, May 2831, 1990

14) Myers, T. D., Hess, J. A. : A study of the effects of a pulsed Nd-YAG laser on human enamel and dentin. Second international society of laser dentistry. world congress, Paris, May 28-31, 1990.

15) Abed, S., Hess, J., Shivapla, A. : Bond strength of orthodontic brackets to acid etched and laser etched enamel. International academy of laser dentistry, Boston, Oct. 13, Abstract, 1990.

16) Huang, S. T., Lin, I. S. and Tsai, C. L. : The effects of different black mediators on the shear strength of orthodontic brackets to the enamel treated with NdYAG laser. Intern Conf on Adv laser Dent. St. Petersburg, Russia. June 20-23, 1994. 
17) Hinoura, K., Moore, B. K. and Phillips, R. W. Ten-sile bond strength between glass ionomer cements and composite resins. J. Am. Dent. Assoc., 114: 167172, 1987.
18) Causton, B. E. and Sefton, J. : Some bonding characteristics of a HEMA/maleic acid abhesion promoter. Br. Dent. J., 167 : 308-311, 1989. 